\title{
STUDIES OF NEW ALBANY SHALE PLANTS. I. STENOKOLEOS SIMPLEX COMB. NOV.'
}

\author{
Charles B. Beck
}

\begin{abstract}
A B S T R A C T
Beck, Charles B. (U. Michigan, Ann Arbor.) Studies of New Albany shale plants. I. Stenokoleos simplex comb. nov. Amer. Jour. Bot. 47(2): 115-124. Illus. 1960-A specimen of Stenokoleos from the Falling Run member of the Sanderson formation is described and shown to belong to the same species as Mesoneuron simplex (Read and Campbell, 1939). Among the distinctive features of this species are traces of triangular shape bearing 3 mesarch protoxylem areas, metaxylem tracheids with scalariform pitting, and the presence of fibers in the outer phloem. The new specimen indicates that Stenokoleos had a basically cruciform xylem strand which gave rise to pairs of traces, each trace supplying one of a pair of lateral appendages which occurred on opposite sides of the main axis, but at different levels. The fern-like nature of Stenokoleos is emphasized and it is suggested that this genus most closely resembles members of the Zygopteri. daceae.
\end{abstract}

THE NEW ALBANy shale of Indiana and Kentucky is particularly interesting for 2 major reasons: (1) its age has long been in controversy; and (2) it contains a diverse and unusually notable petrifaction flora.

In 1946, Campbell presented the results of an extensive stratigraphical study of the New Albany shale. He concluded, primarily on the basis of faunal and lithologic evidence, that the relatively thick lower part (about $90 \mathrm{ft}$. in Indiana), consisting of the Blocher and Blackiston formations and their correlatives, is of Devonian age and that the much thinner upper part (about $11 \mathrm{ft}$. in Indiana), consisting of the Sanderson, Underwood, and Henryville formations and their correlatives, is of Lower Mississippian age. Read (1936a: Read and Campbell, 1939) had previously concluded, primarily on the basis of the flora, that the upper part is Upper Devonian in age, an opinion expressed by several earlier workers (see Campbell, 1946). Read's interpretation of the floral evidence was not supported, however, by Arnold (1948), Cross and Hoskins (195la, 1951b), and Hoskins and Cross (1951, 1952). These workers presented convincing arguments that the floral evidence does, in fact, support Campbell's (1946) conclusion of the Mississippian age of the upper part of the New Albany. This conclusion has also been strengthened, in part, by Hass (1956) who, as a result of a study of conodonts, classifies the Falling Run member of the Sanderson as early Mississippian. He considers the underlying part of the Sanderson to be of Upper Devonian age, however. Since there is still not general agreement on the age of the upper part of

${ }^{1}$ Received for publication June 8, 1959.

This study was assisted by a grant from the Horace $H$. Rackham School of Graduate Studies of the University of Michigan.

I should like to express my appreciation to Drs. S. H. Mamay and G. A. Cooper for their cooperation in making available slides of several specimens in the U. S. National Museum. the New Albany shale, paleontological and paleobotanical studies must be continued in order to resolve this problem. Evidence from my own researches which supports the Lower Mississippian classification of the Falling Run member of the Sanderson will be presented in subsequent papers.

The plants of the New Albany shale are found in greatest abundance in the Falling Run, occurring both within nodules and in the surrounding shale. The plant specimens consist of fragments of stems, roots, petioles, and rarely, fructifications, and are structurally preserved, according to Scott and Jeffrey (1914), largely by calcium phosphate and ferric carbonate. Representatives of all the major vascular plant groups except angiosperms, i.e., psilopsids, lycopsids, sphenopsids, ferns and gymnosperms, have been reported. However, the actual occurrence of true psilophytes among the currently known flora is doubtful. The lower part of the New Albany exhibits a comparative dearth of plants, containing in considerable quantity only silicified Callixylon newberryi Arnold (1931) and compressions of Protosalvinia (Foerstia; see Arnold, 1954).

The earliest important study of New Albany shale plants is that of Scott and Jeffrey (1914). They recognized the similarity of the New Albany shale flora to that of the Cypridina shale, Saalfeld Thuringia (Unger, 1856; Solms-Laubach, 1896; Bertrand, 1935). Similar floras also occur in the Wildenfels shale, Saxony (Gothan, 1927), the Lydiennes horizon, Montagne-Noire, France (Bertrand et al., 1935; Böhm, 1935), and the Calciferous sandstone of Great Britain. It is of interest to note that in all of these formations, except the Calciferous sandstone, specimens were similarly preserved in phosphatic nodules. All of these European formations are thought to be of Lower Mississippian age except the Lydiennes horizon, which is slightly younger, probably of Viséan (lower Middle Mississippian) age (Cross and Hos- 
kins, 1951a). Subsequent to the initial work of Scott and Jeffrey, several papers dealing with New Albany shale plants have appeared (Arnold, 1931; Read, 1935, 1936a, 1936b, 1937; Read and Campbell, 1939; Hoskins and Cross 1951, 1952; Cross and Hoskins, 1951a, 1951b; Andrews and Alt, 1956). By far the most extensive work is that of Read. With the exceptions of his rather thorough studies of the Calamopityeae, however, his work has been mostly a survey of genera and species for use in stratigraphy. Detailed anatomical studies are, therefore, badly needed in order to more accurately interpret the morphology and determine the taxonomic affinities of these interesting and often enigmatic plants.

During the past 2 years, I have collected extensively in the New Albany shale and have accumulated specimens of at least 20 of the 32 genera listed by Read and Campbell (1939) as occurring in the New Albany, and at least 1 genus not previously reported from this formation. Considerable credit for my success in collecting is given to Dr. Guy Campbell who gave freely of his extensive and thorough knowledge of this formation, especially in regard to collecting methods and localities. His assistance is very gratefully acknowledged.

The Campbell Collection of New Albany shale fossils, containing a collection of unworked plant material, has recently been acquired by the Museum of Paleontology of the University of Michigan. Professor Chester Arnold has made this material available for study by me and for this I am deeply grateful. An initial examination indicates that several additional genera are represented here.

Detailed studies of these New Albany genera and others, as collected, will be presented in a series of papers. This initial paper deals with Stenokoleos Hoskins and Cross (1951).

One of the 3 known specimens of this genus was originally assigned to Asteroxylon and described by Read and Campbell (1939) as the new species, $A$. setchelli. Arnold (1948) expressed considerable doubt as to the correctness of this generic assignment; and Hoskins and Cross (1951) transferred it to the new genus, Stenokoleos. They emphasized, as had Arnold, that Asteroxylon is known elsewhere from the Middle Devonian only. Furthermore, they noted that it differs from Asteroxylon in the form of the xylem strand, the presence of mesarch pro- toxylem, in cortical histology, and probably in trace arrangement. A second specimen was described in this same paper (Read and Campbell, 1939) as Mesoneuron simplex. Evidence that this specimen is, in fact, Stenokoleos will be subsequently presented, and it will be shown that it and a recently collected specimen, which will be described below, belong to the same species.

DESCRIPTION-The new specimen of Stenokoleos is of exceptional interest because of the excellence of the preservation, and because it consists of a fragment of a stem-like axis bearing the basal portion of a lateral appendage. The discovery in the New Albany shale of axes of different levels of organization in organic connection is extremely rare. This specimen, which adds considerably to our knowledge of Stenokoleos, was collected in the Falling Run member of the Sanderson formation about $5 \mathrm{mi}$. north of New Albany, Indiana. The larger axis fragment was about $2.5 \mathrm{~cm}$. long, and yielded 6 cross sections and 1 longitudinal section. Its lateral appendage, from which 4 cross sections were prepared, was about $1.0 \mathrm{~cm}$. in length. The exact morphological nature of the larger axis and its lateral appendage, i.e., whether they are, respectively, stem and petiole, or petiole and pinna axis, cannot be positively determined on the basis of this specimen.

Anatomy of the main axis.-The main axis (fig. 1-3) has an approximate diameter of $3.5 \mathrm{~mm}$. It contains a protostelic primary xylem strand which is invested by a layer of primary phloem. Pericycle and endodermis are not present, and consequently the cortex and phloem are contiguous. Traces depart from opposite arms of the strand at different levels. The vascular strand measures about $2.0 \mathrm{~mm}$. in greatest dimension, thus occupying a relatively large area in a transverse section of the axis. This results in a relatively narrow cortex. The epidermis is too poorly preserved to give information of much value.

The vascular tissue.-The xylem strand (fig. 1-3) is basically cruciform. One of its arms bears 2 lobes, but it seems very probable that each of these is an incipient trace (fig. 1-3, 11, 17A,B). The pair of traces which departed from the opposite arm at a lower level are present in the cortex (fig. 1-3, 17A). Whether the 2 traces departed separately from the xylem strand or were formed by an early

Fig. 1-9.--These and all other illustrations in this paper are from sections of topotype \#35776 unless otherwise indicated. Fig. 1-5. Stenokoleos simplex. Transverse sections. $\times 18 .-$ Fig. 1. Section illustrating general anatomical features and a pair of traces shortly after departure from the stele.-Fig. 2. A section showing the inward development of sclerenchyma around traces.-Fig. 3. Each trace is completely encircled by sclerenchyma indicating the formation of a pair of lateral appendages.-Fig. 4. A section near the base of the lateral appendage represented in fig. 3 by the wellpreserved trace.-Fig. 5. A section of the lateral appendage cut $6 \mathrm{~mm}$. distant from that shown in fig. 4.-Fig. 6 . Reimanniopsis indianensis. Transverse section. (Slide labeled "Reimannia indianense- 1", in U. S. National Museum). $\times 18 .-F i g .7$. Cf. Stenokoleos. Transverse section. (Slide labeled "Asteroxylon sp. \#1 (9)", in U. S. National Muse$\mathrm{um}) . \times 18 .-F i g .8$. Stenokoleos setchelli. Transverse section. (Slide labeled "Asteroxylun setchelli Read \#2", U. S. National Museum). $\times 18$.--Fig. 9. Stenokoleos simplex. Transverse section of holotype. (Slide labeled "Mesoneuron sim. plex \#6", in U. S. National Museum). $\times 18$. 


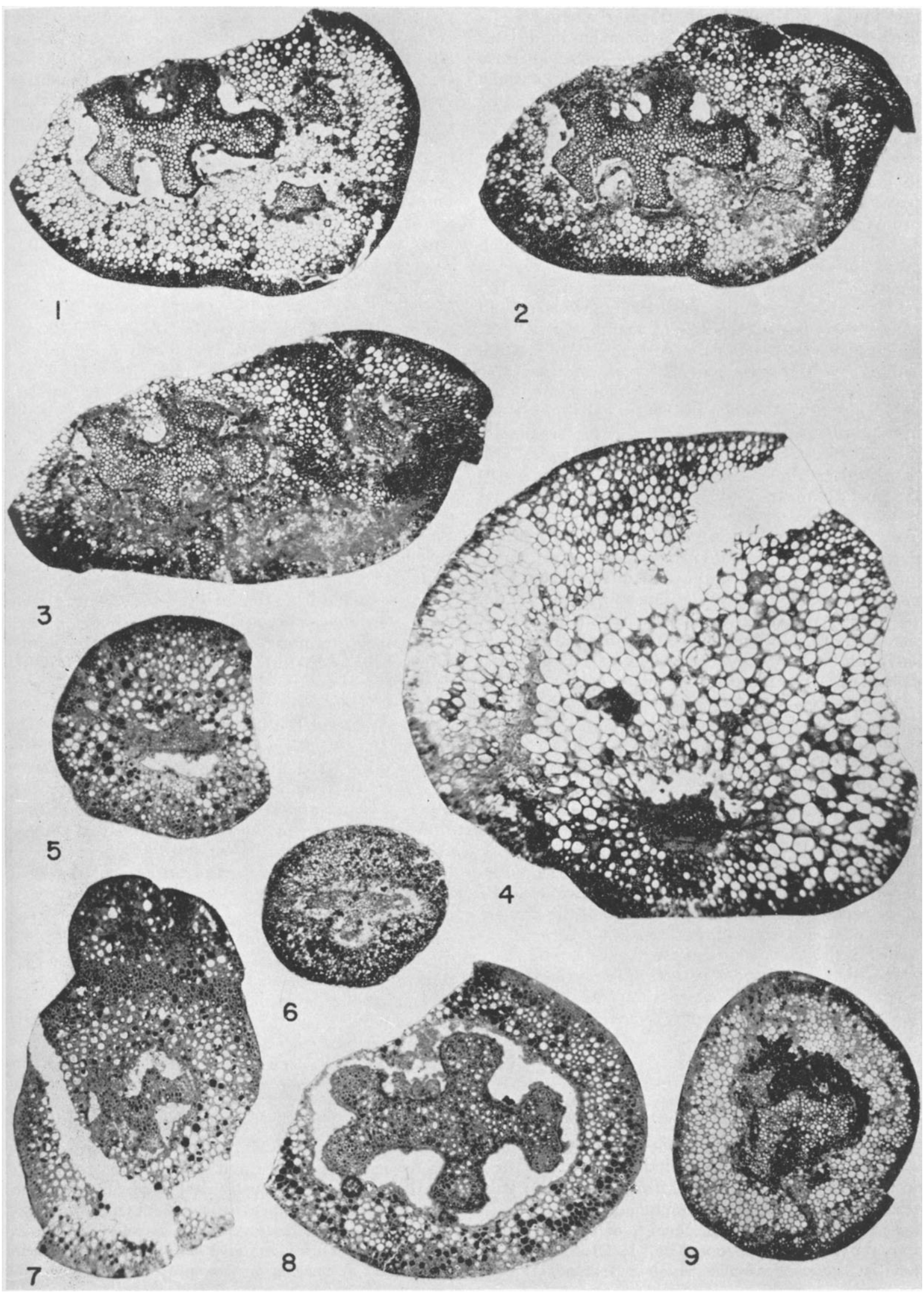


division of a single large trace is unknown. A discussion of this point will be given in a later section of this paper. The arms active in trace production are relatively elongate and essentially opposite whereas the opposing arms are not quite opposite and are somewhat shorter. Although the sub-opposite position of the shorter arms is constant throughout this axis, the evidence is not sufficient to conclude that it is a constant or significant feature of the species. Deeply embedded mesarch protoxylem occurs within the xylem strand (fig. 10, $17 \mathrm{~A}, \mathrm{~B})$. There are 14 protoxylem areas, 3 of which occur in each of the incipient traces, and 8 in the main body of the xvlem strand. The number and relative position of the protoxylem areas remain constant throughout the $2.2 \mathrm{~cm}$. length of axis from which transverse sections were made (fig. 17A,B). The protoxylem elements are small in transverse dimension, increasing in diameter from a minimum of about $11 \mu$. Thick-walled metaxylem elements average about $58 \mu$ in diameter and are frequently pentagonal or hexagonal in transverse view, with their greatest dimension oriented at a right angle to the surface of the xylem strand. The peripheral metaxylem elements are commonly smaller, many about $20-28 \mu$ in diameter (fig. 10). Only 1 rather poor, longitudinal section is available for study, but this gives positive indication of the scalariform nature of the pitting of these elongate cells (fig. 14). Although this is an extremely well-preserved specimen, the longitudinal section is disappointing, as in other New Albany shale material, and fine details of wall sculpturing are not visible.

The phloem.--Surrounding the xylem strand is an essentially parenchymatous tissue which, apparently, is the phloem (fig. 10, 17A,B). It is of nearly uniform thickness, being only slightly thicker in the bays between arms of xylem than around the ends of the arms. The several innermost layers contain large, angular, thin-walled cells (fig. 10) with transverse dimensions of as much as $38 \times 57 \mu$. Associated with these cells, which have the appearance of sieve cells, are small cells which may be phloem parenchyma. The outer part of the phloem tissue contains, in addition to rather large thinwalled cells, thick-walled fiber-like cells (fig. 10) which give this tissue a very characteristic appearance. They are nearly circular in transverse form and vary greatly in diameter, from 17 to $47 \mu$. The occurrence of fibers in the phloem is one of the most unexpected features of this plant since sclerenchyma in the primary phloem of pteridophytes, both extant and extinct, seems to be very uncommon. Although it has been impossible to observe these cells in longitudinal section, there seems to be little doubt that they are, indeed, fibers. Their occurrence in the outer region of the phloem suggests that they may be protophloem fibers.

The cortex. - This tissue consists of a broad inner, and a narrow outer zone (fig. 1,2). The inner zone is composed of cells which appear nearly oval to circular, but which are, in fact, angular. They commonly vary from 34 to $98 \mu$ and increase gradually in wall thickness toward the outside of the stem. Conspicuous intercellular spaces characterize this inner zone (fig. 13). There is an abrupt transition between the relatively large cells of this zone and the generally smaller and thicker-walled cells of the outer zone. The outer zone is composed of alternating clusters of thick-walled sclerenchymatous cells and bands of thinner-walled cells of similar shape and size as seen in transverse view, and has the appearance of a hypodermis (fig. 13). The cells of this zone have an average diameter of about $25 \mu$. The cortex was bounded by an epidermis of which only vestiges remain.

Traces and trace departure.-Pairs of traces originate from opposite arms of the vascular column of the main axis. Each trace (fig. 1, 17A) is composed of a triangular xylem strand surrounded by phloem. There are 3 protoxylem areas, 1 in each corner of the trace. The presence and position of 3 protoxylem areas in each of the lobes of the arm opposite that from which traces departed at a lower level (fig. 11, 17A,B) are convincing evidence that these lobes are incipient traces. The shape and position of the lobes strengthens this conclusion. A comparison of the form of the xylem strand in the first and last transverse sections of the series made from the main axis of this specimen show the lobes becoming more extended (fig. $17 \mathrm{~A}, \mathrm{~B})$. Furthermore, the opposite arm is becoming enlarged prior to formation of another pair of incipient traces (fig. 17B). Since in no known specimen of Stenokoleos can the actual departure of traces be observed, it is impossible to state positively whether the 2 traces originated separately, or as the result of a precocious division of a single larger trace. The latter is conceivable, assuming a very gradual and steep angle of trace departure. However, because of the shape of the traces, their orientation as compared with that of the incipient traces, and their proximity to the arm of the stele which gave rise to them, it is probable that they originated separately.

Anatomy of the lateral appendage.-The base of the lateral appendage is indicated in transverse section by an increase in size of the part of the axis containing the pair of traces (fig. 1). There is an inward development of sclerenchyma (fig. 2) which finally encloses each of the traces (fig. 3). Unfortunately, the specimen was badly crushed at the node and shows signs of decay in the vicinity of one of the traces. The position of this trace is, however, clearly defined by the enclosing sclerenchyma, and the presence of several fibers of the phloem, but the tissues of the trace and surrounding parenchyma tissue have been mostly destroved (fig. 3). The enclosure of each trace by sclerenchyma is sound indication of the formation of a pair of lateral appendages. Unfortunately, only one of these is preserved. A section of the preserved lateral ap- 


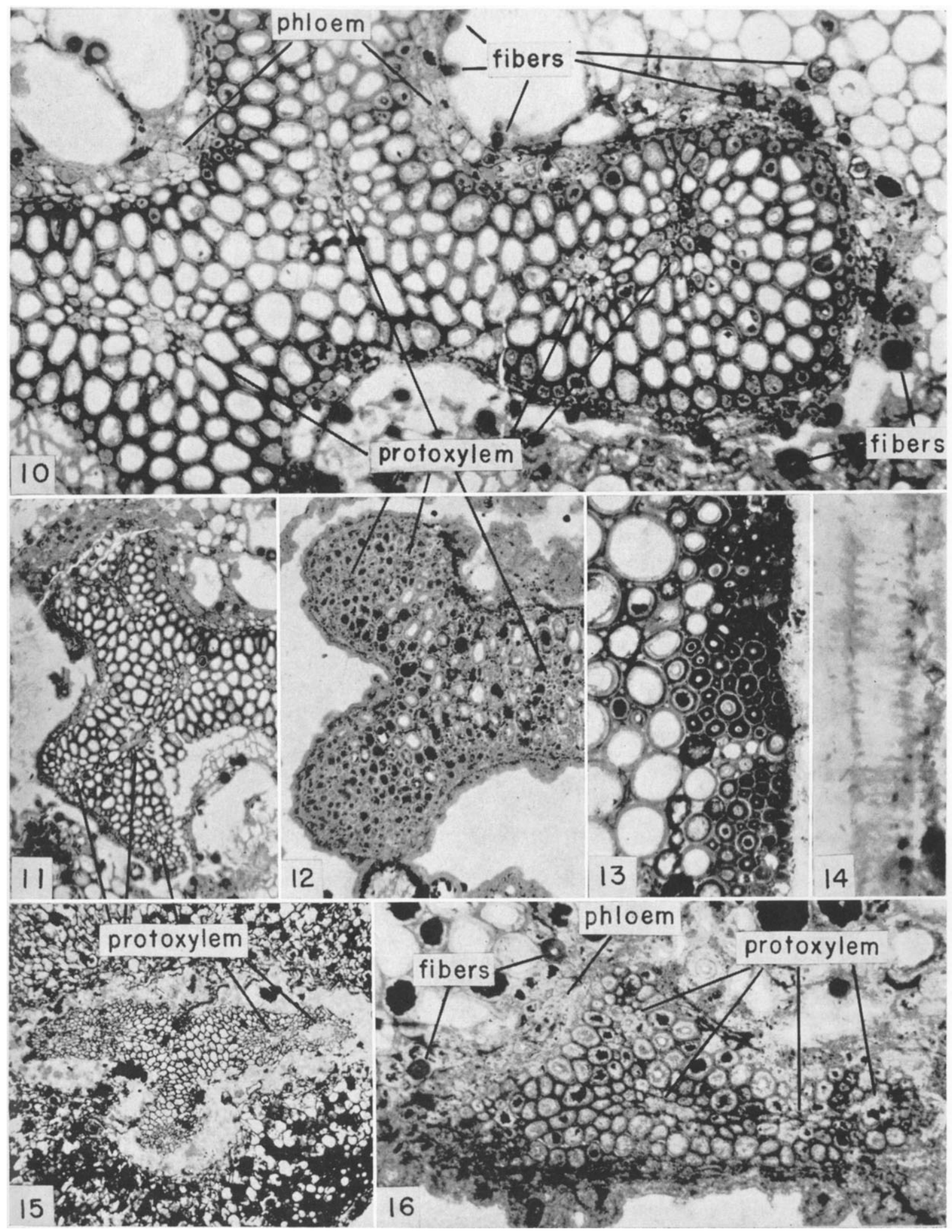

Fig. 10-16.-Fig. 10, 11. Stenokoleos simplex.-Fig. 10. Transverse section illustrating details of vascular tissues of the main axis. $\times 108$. - Fig. 11. Transverse section showing arm of the stele bearing 2 incipient traces. $\times 52 .-F i g .12$. Stenokoleos setchelli. Transverse section showing arm of the stele bearing two incipient traces. $\times 52 .--F i g .13$, 14. Stenokoleos simplex.-Fig. 13. Transverse section showing zonation of the cortex. $\times 108 .-$ Fig. 14 . Longitudinal section of a scalariform metaxylem element. $\times$ 418. - Fig. 15. Reimanniopsis indianensis. Transverse section showing structural details of the vascular strand. Compare with fig. 16. $\times 52 .-F i g .16$. Stenokoleos simplex. Transverse section illustrating details of vascular strand of the lateral appendage. $\times 108$. 

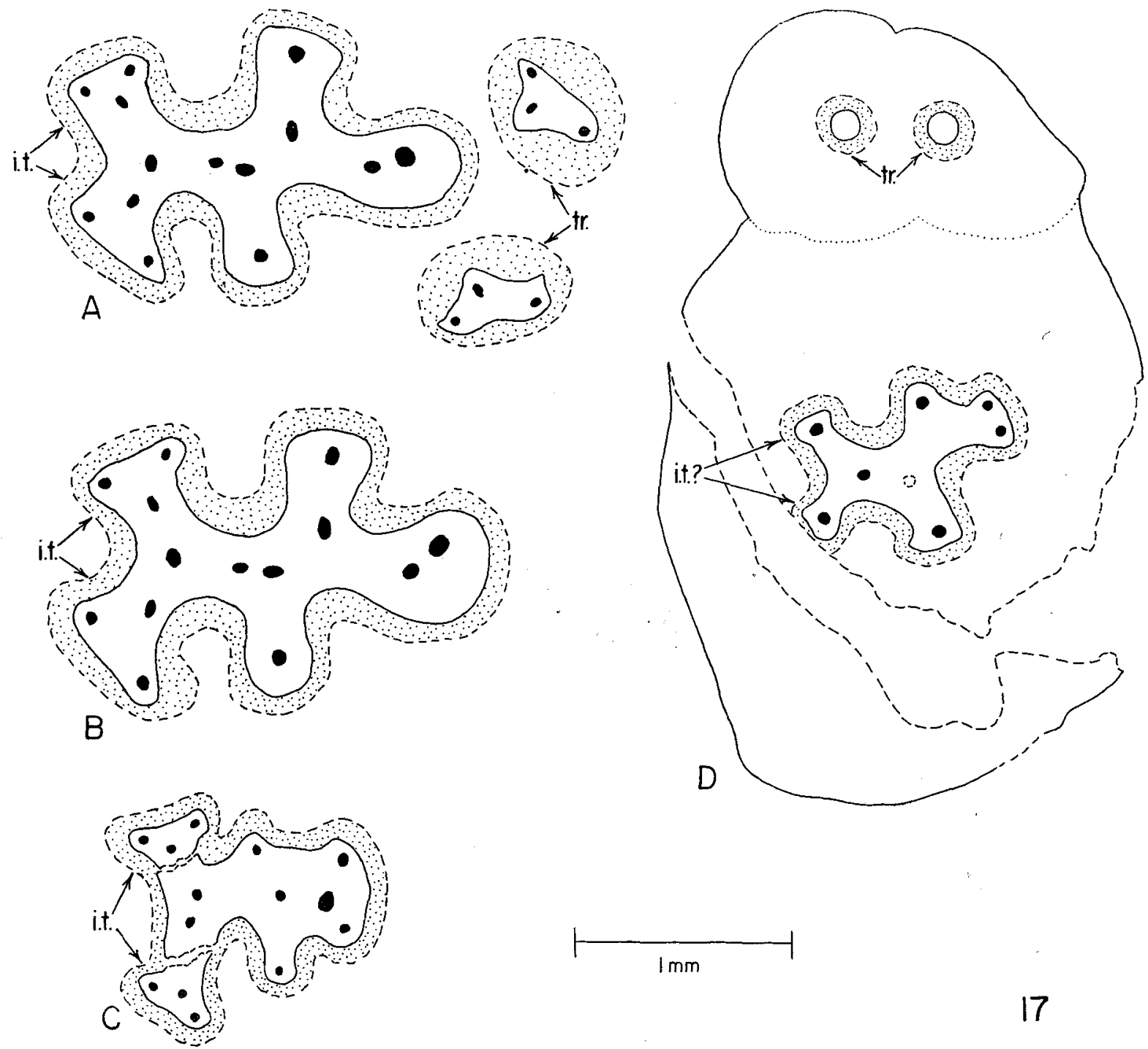

Fig. 17. Diagrams of transverse sections of Stenokoleos simplex (17A-C), and Cf. Stenokoleos (17D). Protoxylem is represented by black dots; xylem of main vascular strand and traces is enclosed by phloem (stippled), the approximate outer limit of which is indicated by a dashed line; i.t. $=$ in cipient trace, $\operatorname{tr}=\operatorname{trace} .-A$. First of a series of 6 transverse sections. Arm from which traces have recently departed is relatively slender; incipient traces are short.-B. Last of same series of 6 transverse sections. Incipient traces becoming more distinct prior to trace departure; arm from which traces previously departed becoming enlarged prior to formation of another pair of incipient traces.-C. From slide labeled "Mesoneuron simplex \#10", in U. S. National Museum.-D. The outer solid line represents the epidermis; the dotted line indicates the inner edge of the sclerenchyma which separates the main axis from the base of a probable pair of lateral appendages. Prepared from the slide illustrated by a photograph in fig. 7 .

pendage, cut at an angle of about $90^{\circ}$ and as close as possible to the main axis, is illustrated in fig. 4 . This is greatly swollen at the base with a diameter of $5 \mathrm{~mm}$. but abruptly decreases to a diameter of $2.2 \mathrm{~mm}$. at a distance of about $6 \mathrm{~mm}$. (fig. 5). (It should be noted that fig. 1-5 are of equal magnification.) The tissue composition of the appendage is similar to that of the main axis, but in the swollen basal part, the parenchyma cells of the cortical region have thinner walls and are 2-3 times greater in diameter. The peripheral tissue is a narrow sclerenchymatous layer similar to that of the main axis, although it is narrower and less well-defined in the swollen basal part. The vascular strand retains the same triangular form of the trace (fig. 3-5, 16). As in the main axis, the xylem is enclosed by phloem which is characterized by the presence of a few random fibers in the outer part of the tissue (fig. 16). As would be expected, the base of the triangular vascular strand is oriented toward the abaxial side of the lateral appendage. The only significant change noted in the strand throughout 
its preserved length is a proliferation of protoxylems. In the section most distant (about $8 \mathrm{~mm}$.) from the main axis, the xylem strand apparently contains 6 protoxylem areas. In addition to the 3 original ones, there is one centrally located, and a single additional area can be observed in one of the lateral extensions of the strand (fig. 16). A similar proliferation probably occurred in the opposite lobe, but this cannot be positively determined because of paor preservation. This proliferation of protoxylem may indicate subsequent trace formation.

MESONEURoN SIMPLEX READ AND CAMPBELL.-A small axis was briefly described, illustrated by a single transverse, and designated Mesoneuron simplex sp. nov. by Read and Campbell (1939). This plant was described in part as follows: "2. Protostele irregularly lobate, tending to be $\mathbf{T}$. shaped, protoxylem points several, mesarch." These workers suggested that "This form is clearly related to Mesoneuron tripos of Unger. Its affinities are for the present highly problematical." Examination of the primary xylem strand in the 11 available transverse sections of Read and Campbell's specimen shows that it is, indeed, irregularly lobate (fig. 9, 17C) but hardly $\mathbf{T}$-shaped. Furthermore, in my opinion, it bears little resemblance to that of Mesoneuron tripos which according to Unger's illustration and description (1856), is sub-triangular in transverse section. A comparison of this specimen with the new specimen described above indicates that they belong to the same species. The primary xylem strand of $M$. simplex has a distorted appearance which is due in part to a crushing of the specimen. It is, however, basically cruciform, and undoubtedly gives rise to pairs of triangular traces from opposite sides of the strand. Each incipient trace contains 3 mesarch protoxylem areas (fig. 17C). These characters are identical with those of the new specimen. It is interesting to note, also, that the xylem strand of each specimen contains 14 protoxylem areas although their positions in the 2 specimens differ slightly (fig. 17B,C). Each specimen is characterized by the conspicuous, randomly scattered fibers in the outer phloem, and all details of the cortex, including size of cells, are identical. Finally, both specimens were collected from the same horizon at the same locality. There can be no doubt that these specimens represent the same species.

Evidence for a generic assignment of these specimens to Stenokoleos is strong. The combination of a basically cruciform primary xylem strand with 1 arm strongly bilobed, large mesarch protoxylem areas, cortex proportionately narrow in relation to the size of the stele and composed of 2 zones, the outer narrower zone of hypodermal nature, is characteristic of both Stenokoleos setchelli (fig. 8, 12) and these specimens. It is unlikely that two different genera of the same age, and from the same locality, would share such a combination of characters.

CF. stenokoleos.-Hoskins and Cross (1951) de- scribed a single transverse-oblique section of a plant showing the origin of "a foliar member" containing 2 circular vascular strands and suggested that it might be another specimen of Stenokoleos setchelli. A discussion of this specimen is included here because of its possible contribution to a more complete understanding of the arrangement of the pairs of lateral appendages in Stenokoleos. As a result of the investigation of the new specimen of Stenokoleos it is certain that lateral appendages were produced in pairs on opposite sides of the main axis at different levels in this genus. It is not possible, however, to determine whether the pairs of appendages were 2- or 4-ranked. I have examined a similar slide of the same specimen studied by Hoskins and Cross (fig. 7, 17D), and find that it has many points of similarity with Stenokoleos. The xylem strand gives the impression of being irregularly cruciform, with one arm bilobed. The lobes may be incipient traces (fig. 17D). There are probably 8 mesarch protoxylem areas, and the cortex is composed of 2 distinct zones, similar to those of Stenokoleos. The base of a lateral appendage contains 2 traces, and there is indication of a branching which would result in a pair of appendages. There is an indentation in the outer surface and a similar opposing indentation of the sclerenchyma which separates the base of the structure from the main axis (fig. $7,17 \mathrm{D}$ ). In overall size, the axis falls within the range of the known specimens of Stenokoleos. The most conspicuous difference between this specimen and Stenokoleos is the proportionately smaller area of the stem occupied by vascular tissue. The circular shape of the xylem strand of the traces contrasts with the triangular shape of those in the new specimen of Stenokoleos, but a strand of similar transverse shape would be expected in $S$. setchelli and is probably of significance only in species delimitation.

If this is another specimen of Stenokoleos it is of particular importance because it seems to supply evidence of a tetrastichous arrangement of the pairs of lateral appendages. The 2 lobes of the xylem strand which may be incipient traces are not opposite the base of the lateral appendages in this specimen, but occur on an arm of the xylem strand at a right angle to that from which traces previously departed. Since it is known that successively formed pairs of appendages were produced on opposite sides of the stem, one can only conclude that this condition indicates a 4-ranked arrangement. Nevertheless, because of the one important difference noted, and the possibility of an incorrect inter. pretation of structure resulting from the oblique. ness and poor preservation of the single section observed, I believe that it is unwise to positively assign this specimen to Stenokoleos. The number of orthostichies of paired appendages must, therefore, remain in doubt.

Stenokoleos Hoskins and Cross, emend.-Diag. nosis.-Small, herbaceous plant producing primary 
tissues only. Diameter of main axis varies (among 3 specimens) from $2.6-4.3 \mathrm{~mm}$. Primary xylem strand cruciform in transverse view, its greatest dimension covering from about $1 / 2$ to $3 / 5$ of the diameter of the axis; protoxylem mesarch; arms which give rise to traces becoming bilobed prior to trace departure; successive pairs of traces produced from opposite arms of the xylem strand. Pairs of lateral appendages occur on opposite sides of the stem, but alternate in position; number of orthostichies uncertain, but possibly 4 ; each of the pair of lateral appendages containing a single vascular strand. Cortex relatively narrow, composed of an inner large-celled zone and a narrower peripheral zone of hypodermal nature.

There are sufficient differences between $S$. setchelli and the new specimen to warrant specific separation. The repetition of these divergent characters in the specimen designated as Mesoneuron simplex (Read and Campbell, 1939) lends support to the belief that they are persistent characters of taxonomic value. These specimens are characterized by angular incipient traces, and traces bearing triangular xylem strands. In $S$. setchelli, the incipient traces are rounded, and the xylem strand of the traces is probably circular in transverse section. Another important point of divergence is in the number of protoxylem areas, there being 10 in $S$. setchell $i^{2}$ and 14 in each of the other specimens. The presence of an identical number of protoxylem areas in each of these specimens may be coincidental. The number probably varied between different individuals of each species, but it seems reasonable to suspect that the relative difference in number between the species remained fairly constant. Characters of the phloem and the lateral appendages may also be of specific importance, but since these are not preserved in $S$. setchelli, no comparison is currently possible. The species, Mesoneuron simplex, supplemented by the new specimen described herein, is recombined with the genus, Stenokoleos, and redefined.

Stenokoleos simplex (Read and Campbell) Beck, comb. nov. et emend.-1939. Mesoneuron simplex Read and Campbell, Amer. Midl. Nat. 2I: 443 , pl. 5 , fig. 1 .

Emended diagnosis.--Primary xylem strand containing 14 protoxylem areas; metaxylem tracheids scalariformly pitted. Lobes of the stelar strand of the main axis, representing incipient traces, of angular configuration; xylem strand of traces triangular, containing 3 protoxylem areas. Pericycle and endodermis absent. Primary phloem characterized by peripherally located, thick-walled, fiber-like cells. Base of lateral appendages greatly enlarged (exceeding by about $1 / 3$ the diameter of the main

${ }^{2}$ Hoskins and Cross (1951) reported 8 protoxylem areas in Stenokoleos setchelli. My observations, however, indicate the presence of 2 protoxylem areas in each of the incipient traces as illustrated in fig. 12 , resulting in a total of 10 . axis) but decreasing in size by more than 2 -fold in a distance of about $6 \mathrm{~mm}$.

Holotype.-Slides labeled "cf. Asteroxylon," numbers 2 and 3 ; and "Mesoneuron simplex," num. bers 4-7 and 9-13 in the U. S. National Museum, Washington, D. C. (These 11 slides are from the same series, of which numbers 1 and 8 are missing.)

Topotype.-Eleven slides bearing the number 35776 in the Museum of Paleontology, University of Michigan, Ann Arbor, Michigan.

Horizon.-Falling Run member of the Sanderson formation (Upper Devonian or Lower Mississippian), New Albany shale.

Locality._"Nodule Bed," New Albany, Floyd County, Indiana.

Discussion.-Two genera, Tetrastichia Gordon (1938) from the Lower Carboniferous of Scotland and Tetraxylopteris Beck (1957) from the Upper Devonian of New York, exhibit superficial resemblances to Stenokoleos. These plants possess a cruciform primary xylem strand but are also characterized by the production of large amounts of secondary vascular tissues. Hoskins and Cross (1951), without a knowledge of the branching pattern of Stenokoleos, presented a strong argument for the separation of this genus from Tetrastichia. Their conclusion is supported by the additional evidence now available. In Stenokoleos the production of pairs of lateral appendages on opposite sides of the axis at different levels contrasts markedly with the subopposite and decussate arrangement of lateral appendages in Tetrastichia. Tetraxylopteris is characterized by the production of a single diamondshaped trace, single lateral axes in a sub-opposite and decussate arrangement, secondary tissues, and pits of the round-bordered type, all of which contrast with characters of Stenolioleos.

Both Tetrastichia and Tetraxylopteris, while exhibiting an interesting combination of fern and pteridosperm characters, seem to be more closely allied to the Pteridospermales. Stenokoleos, however, is more fern-like. The lack of secondary tissues, the presence of scalariform pitting, the concentric arrangement of vascular tissues, and the occurrence of mesarch protoxylem area are all fern characteristics.

The protoxylem areas in the ends of the arms of the xylem strand are conspicuous, and contain considerable parenchyma as well as tracheary elements. They resemble most closely the peripheral "loops" of clepsydropsoid zygopterids such as Metaclepsydropsis and Asterochlaena. In the presence of several internal protoxylem areas, and the more or less radial symmetry of the stele, the main axis of Stenokoleos resembles most closely the stems of Ankyropteris and Asterochlaena, both of which are clepsydropsoid coenopterid genera. The protoxylem of Ankyropteris is commonly reported to occur at the periphery of narrow parenchymatous regions which extend from a pith-like center into the lobes of the stele. Baxter (1951), however, reports 
exarch protoxylem in the stem of $A$. glabra but in his diagnosis states only that there is "a five lobed actinostele consisting of a pentarch network of small tracheal cells surrounded by much larger metaxylem cells." The disposition of protoxylem in Asterochlaena is similar to that in Ankyropteris, but differs in that the protoxylem occurs in essentially unparenchymatous radial bands extending through the middle of each arm of the stele (Scott, 1920). The difference between these conditions (especially that of Ankyropteris) and that in Stenokoleos in which the rather parenchymatous protoxylem areas are separated by metaxylem is, perhaps, only one of degree. The numerous internal protoxylem areas and the stelar form of the vascular column suggest that the main axis of Stenokoleos is a stem. On the other hand, the production of pairs of lateral appendages on opposite sides of the axis at alternate levels is similar to pinnae production in the etapteroid zygopterids and is suggestive of its possible petiolar nature. Current evidence seems to favor a conclusion that the main axis of Stenokoleos is a stem.

The form of the xylem strand of the lateral appendage of Stenokoleos is similar to that of the Middle Devonian species, Reimannia aldenense Arnold (1935), and the Lower Mississippian (or Upper Devonian) species, Reimanniopsis indianensis (Read and Campbell) Hoskins and Cross (1951). According to Arnold (1947, p. 172), traces depart from each lobe of the xylem strand of Reimannia. The available evidence indicates possible trace formation by only 2 of the lobes of the strand in the lateral appendage of Stenokoleos. In this respect it is more similar to Reimanniopsis. In the most distal section of the lateral appendage of Stenokoleos (fig. 16) and in Reimanniopsis (fig. 15) the elongate lobes contain 2 protoxylem areas, apparently indicating subsequent trace departure. Reimanniopsis is further similar in transverse diameter, in cortical zonation, and in the apparently concentric arrangement of xylem and phloem. The xylem strand of Reimanniopsis is somewhat larger, and more nearly T-shaped (fig. 15) than that of the triangular strand of Stenokoleos. It also apparently occupies a greater proportion of the total area of the axis in transverse section (compare fig. 5,6). Reimanniopsis, which was collected from the same horizon and at the same locality as Stenokoleos, probably represents a comparable part of this or a similar plant.

Arnold (1940) recognized the fern-like nature of Reimannia and included it with two other Middle Devonian genera, Arachnoxylon and Iridopteris, in the Iridopteridineae of the Coenopteridales. In gross structural organization both of the latter genera resemble the main axis of Stenokoleos. Arachnoxylon, which has a distinctly actinostelic xylem strand, is the more similar, but because of poor preservation of other tissues and a lack of knowledge of its branching pattern a detailed com- parison with Stenokoleos is impossible. The occurence of relatively complex forms such as Stenokoleos in the Lower Mississippian (or Upper Devonian), and Rhachophyton (Leclercq, 1951) in the Upper Devonian indicates an early origin of the Coenopteridales and supports Arnold's inclusion of the iridopterid ferns in this order. The resemblance between the main axis of Stenokoleos and Arachno$x y l o n$ and between the lateral appendage of Stenokoleos and Reimannia suggests the possibility that the Iridopteridineae, instead of being ferns of relatively simple construction, may be parts of somewhat more complex types.

At present it seems unwise to assign Stenokoleos to a definite taxon above genus. However, it should again be emphasized that it most closely resembles members of the Zygopteridaceae; and it will probably be assigned ultimately to this group.

Department of Botany

UNIVERSITY OF Michigan

Ann Arbor, Michigan

\section{LITERATURE CITED}

Andrews, H. N., and K. S. Alt. 1956. A new fossil plant from the New Albany shale with some comments on the origin of land vascular plants. Part 1. Crocalophyton, a new transitional sea-land plant. Part 2. Some comments on the origin of land vascular plants and the taxonomic position of Crocalophyton. Ann. Missouri Bot. Gard. 43: 355-378.

ARnold, C. A. 1931. On Callixylon newberryi (Dawson) Elkins et Wieland. Contr. Mus. Paleontol. Univ. Michigan 3: 207-232.

- 1935. New forms and new occurrences of fossil plants from the Middle and Upper Devonian of New York State. Bull. Buffalo Soc. Nat. Sci. 17: 1-12.

- . 1940. Structure and relationships of some Middle Devonian plants from western New York. Amer. Jour. Bot. 27: 57-63.

- 1947. An introduction to paleobotany. McGrawHill Book Co., Inc. New York.

- 1948. The Mississippian flora. Jour. Geol. 56: 367372.

- 1954. Fossil sporocarps of the genus Protosalvinia Dawson, with special reference to $P$. furcata (Dawson) comb. nov. Svensk Bot. Tidskr. 48: 292-300.

Baxter, R. W. 1951. Ankyropteris glabra, a new American species of the Zygopteridaceae. Amer. Jour. Bot. 38: $440-452$.

Beck, C. B. 1957. Tetraxylopteris schmidtii gen. et sp. nov., a probable pteridosperm precursor from the Devonian of New York. Amer. Jour. Bot. 44: 350-367.

Bertrand, Paul. 1935. Contribution a l'étude des Cladoxylées de Saalfeld. Palaeontographica 80B : 101-170.

— R. Böhm, and Paul Corsin. 1935. Découverte d'une flore dans les Lydiennes du Carbonifère de la Montagne-Noire a Saint-Nazaire-de-Laderez (Hérault). Compt. Rend. Acad. Sci. Paris 200: 1344-1345.

Böнm, R. 1935. Etude sur la flore de l'horizon a Lydiennes de la base du Carbonifére de la Montagne Noire. Imprimerie de la Charité, Montpellier, pp. 1-29.

Camprell, Guy. 1946. New Albany shale. Bull. Geol. Soc. Amer. 57: 829-908.

Cross, A. T., and J. H. Hoskins. 195la. Paleobotany of the Devonian-Mississippian black shales. Jour. Paleontol. $25: 713-728$. 
_. AND - 195lb. The Devonian-Mississippian transition flora of east-central United States. Compte rendu: 3rd Congrès de Strat, et de Géol. du Carbonifére, Heerlen. pp. 113-122.

Gordon, W. T. 1938. On Tetrastichia bupatides: a Carboniferous pteridosperm from East Lothian. Trans. Roy. Soc. Edinburgh 59: 351-370.

Gothan, W. 1927. Strukturzeigende Pflanzen aus dem Oberdevon von Wildenfels. Abh. Sächs. Geol. Landes. 3: 1-11.

Hass, W. H. 1956. Age and correlation of the Chattanooga shale and the Maury formation. U. S. Geol. Surv. Prof. Paper 286: 1-47.

Hoskins, J. H., And A. T. Cross. 1951. The structure and classification of four plants from the New Albany shale. Amer. Midl. Nat. 46: 684-716.

-, AND 1952. The petrifaction flora of the Devonian-Mississippian black shale. The Paleobotanist 1: $215-238$.

LECLERCQ, S. 1951. Étude morphologique et anatomique d'une fougère du Dévonien Supérieur. Le Rhachophyton zygopteroides nov. sp. Ann. Soc. Géol. Belgique 9: 1-62.

READ, C. B. 1935. An occurrence of the genus Cladoxylon Unger, in North America. Jour. Washington Acad. Sci. 25: 493-497. 1936a. A Devonian flora from Kentucky. Jour. Paleontol. 10: 215-227.

- 1936b. The flora of the New Albany shale. Part 1. Diichnia kentuckiensis, a new representative of the Calamopityeae. U. S. Geol. Surv. Prof. Paper 185-H, pp. 149-155.

- 1937. The flora of the New Albany shale. Part 2. The Calamopityeae and their relationships. U. S. Geol. Surv. Prof. Paper 186-E, pp. 81-91.

- and GuY Campbell. 1939. Preliminary account of the New Albany shale flora. Amer. Midl. Nat. 21: $435-453$.

Scotr, D. H. 1920. Studies in fossil botany, vol. 1, 3rd ed. A. and C. Black, Ltd. London. - AND E. C. JEFFrEY. 1914. On fossil plants, showing structure, from the base of the Waverley shale of Kentucky. Phil. Trans. Roy. Soc. London B205: 315-373.

Solms-Laubach, H. 1896. Ueber die seinerzeit von Unger beschriebenen strukturbietenden Pflanzenreste des Unterculm von Saalfeld in Thüringen. Abh. König. Preuss. Geol. Landes. 23: 1-100.

Unger, F. 1856. Zweiter Theil. Schiefer und Sandsteinflora. In Richter, R., And F. Unger. Beitrag zur Paläontologie des Thüringer Waldes. Denkschr. Kaiser. Akad. Wiss. Wien 11: 139-186.

\title{
CHROMOSOME NUMBERS IN COMPOSITAE. I. ASTEREAE
}

\author{
Peter H. Raven, Otto T. Solbrig, Donald W. Kyhos, and Richard Snow
}

\section{A B S T R A C T}

Raven, Peter H. (U. California, Los Angeles.), Otto T. Solbrig, Donald W. Kyhos, and Richard SNow. Chromosome numbers in Compositae. I. Astereae. Amer. Jour. Bot. 47 (2) : 124132. Illus. 1960.- Ninety-two new counts are reported for the tribe Astereae of Compositae, mostly based on determinations of meiotic material. These include the first counts reported for the genera Acamptopappus, Amphipappus, Benitoa, Chrysothamnus, Corethrogyne, Lessingia, Monoptilon, and Xanthocephalum, as well as for many species. The original counts are discussed in relation to those previously reported for the tribe; together these constitute a total of 39 genera examined cytologically out of the approximately 100 known. Because of its widespread occurrence in diverse phylogenetic lines within the tribe and the family, and because of its high degree of correlation with the woody habit, which is thought to be primitive, $x=9$ is regarded as the original basic number for Astereae. Within the Haplopappus alliance there is a strong secondary mode of chromosome numbers centering around $x=5$. The hiatus between these two modes in number is explained on the basis of ancient phylogenetic reduction in chromosome number followed by the extinction of less successful intermediate types, and is compared with similar trends that have been reported for Cichorieae. It is suggested that the family is not of polyploid origin but may have had an original diploid basic number.

THE PURPOSE of this series of papers is to report original counts of chromosome numbers in the family Compositae, to compare them with numbers reported in the literature, and to apply the conclusions so attained to a better understanding of the systematics and phylogeny of the group. Although 2 groups within the family, Cichorieae (Stebbins et el., 1953) and Madinae (Carlquist, 1959), are chromosomally among the best known groups of angiosperms, our knowledge of the other tribes is generally poorer. Especially the rich assemblages

1 Received for publication June 13, 1959. of genera and species found in South America, Australia, and Africa have searcely been studied cytologically.

The present treatment is a combined effort, but the authors have worked nearly independently, although there have been occasional opportunities for collaboration. Unless otherwise indicated, the counts have been made from aceto-carmine or acetoorcein squashes of microsporocytes in meiosis. Compositae generally have proven very favorable cytologically with diakinesis usually the best stage for observations, as may be seen in fig. 1-16. 